\section{Two Cases of Acatalasia in Switzerland}

Acatalasia, an inherited defect in the enzyme pattern of red cells and other tissues, has been detected by TAKAHARA and MIYAMOTO in $1947^{1}$. So far 53 cases of this abnormity-all of them Japanese subjects-have been reported ${ }^{2}$. Since no case has been found yet in Western countries, it might be of interest that recently two cases have been observed in Switzerland. This was noticed in a screening test for acatalasia covering all blood samples examined 1961 in the Army Blood Group Laboratory of the Swiss Red Cross Blood Transfusion Service. It merely consists of mixing a drop of a $3-5 \%$ red cell suspension in saline with 1 drop of $1 \%$ phosphate-buffered $\mathrm{H}_{2} \mathrm{O}_{2}-$ solution ( $\mathrm{pH} 7.2$ ). Up to June 29th, 18459 blood samples

Catalase-activity and hemoglobin-content in dilute hemolysates of red cells from normal humans and two cases of acatalasia

\begin{tabular}{|c|c|c|c|}
\hline No. & $\begin{array}{l}\text { Catalase-activity } \\
\text { expressed as } \\
\mathrm{m} \mathrm{Eq} \mathrm{H}_{2} \mathrm{O}_{2} \\
\text { decomposed per } \\
\text { ml of hemolysate }\end{array}$ & $\begin{array}{l}\text { mg } \\
\text { Hemoglobin } \\
\text { per ml of } \\
\text { hemolysate }\end{array}$ & $Q \frac{\mathrm{m} \mathrm{Eq} \mathrm{H} \mathrm{H}_{2} \mathrm{O}_{2} \text { decomp. }}{\mathrm{mg} \text { hemoglobin }}$ \\
\hline $\begin{array}{l}1 \mathrm{~F} . \mathrm{V} . \\
\text { (Acatalasia) }\end{array}$ & 0.25 & 38.0 & $0.66 \times 10^{-2}$ \\
\hline $2^{a}$ (normal) & 65.0 & 28.8 & 2.26 \\
\hline $\begin{array}{l}3 \text { A.B. } \\
\text { (Acatalasia) }\end{array}$ & 0.30 & 20.2 & $1.48 \times 10^{-2}$ \\
\hline $4^{\circ}$ (normal) & 33.2 & 15.9 & 2.10 \\
\hline
\end{tabular}

a Normal subjects of the same sex, age and region, whose blood has been handled in the same way.

\section{Cholinesterase Activity within the Renal Tissue of Helostoma temmincki}

As no literature data are available on this subject, we studied the cholinesterase activity within the renal tissue of the Teleost Helostoma temmincki Cuvier (Anabantidae), using the technique of COUPLAND and HOLMES ${ }^{1}$ and the nomenclature of AUGUSTINSSON and NACHMANSOHN ${ }^{2}$. For this purpose the fishes were killed by decapitation, after which the kidneys were excised and frozen sections cut at $50 \mu$ and stained for true cholinesterase ${ }^{1}$. According to the prescription of GILBERT ${ }^{3}$, also paraffin sections were obtained by cutting $1 \mathrm{~mm}$ slices from the kidneys and laying them in the substrate at $37^{\circ} \mathrm{C}$ for $18 \mathrm{~h}$, the subsequent treatment being according to CoUPLAND and HoLMES ${ }^{1}$. After this, the tissue was embedded in paraffin and sectioned in the normal way. As in the domestic fowl ${ }^{3}$, with this method the very heavy deposit on the surface of the block tended to obscure a certain amount of detail, but with thin sections the same results were obtained as with the frozen sections. The pseudocholinesterase was also demonstrated in both methods by substituting butyrothiocholine iodide as substrate. According to the method of GEREBETZOFF ${ }^{4}$, the controls were obtained by a preliminary incubation of the sections in $1 \times 10^{-7}$ di-isopropylfluorophosphonate.

As in the kidney of domestic fowl ${ }^{3}$, the distribution of both true and pseudocholinesterase was very similar, but the degree of staining for the two enzymes appeared to differ considerably. Both enzymes were observed in quantity in the vascular system, although this could be have been examined. The only persons among these males of 19 years having shown this anomaly so far, are F. V. from Riddes (Canton Valais) and A. B. from Flerden (Canton Graubünden).

The hemolysate of centrifuged red cells of these subjects behaves as indicated in the Table. It can be seen from it that its Catalase activity as determined by FeINSTEIN's Perborate-method ${ }^{3}$ is about $1 / 2 \%$ as compared with that of red cells from a normal subject. As a base of comparison, the ratio Catalase/Hemoglobin (determined as Cyan-Methemoglobin) has been chosen.

According to the record of the medical examination, both subjects are in a good state of health. A thorough investigation of the red cell and serum-enzyme pattern of these subjects, as well as other members of these families, is under way.

Zusammenfassung. Es wird uber 2 Fälle von Akatalasie, einem seltenen, bisher ausschliesslich bei Japanern beobachteten Enzym-Defekt, berichtet ${ }^{4}$.

\section{H. Aebi, J. P. Heiniger, R. BürLer, and A. HÄssig}

Medizinisch-chemisches Institut der Universität Bern und Zentrallaboratorium des Blutspendedienstes des Schweizevischen Roten Kreuzes, Bern (Switzerland), July 10, 1961.

1 S. Takahara and H. Miyamoto, J. otorhinolaryngological Soc. Japan 51, 163 (1948).

2 Personal communication from Dr. Kozoo Kazrro (Sept. 1960).

3 R. N. Felnstein, J. biol. Chem, 180, 1197 (1949).

4 Note added in proof (September 11): Within the family of these persons 4 more cases of acatalasia and a number of hypocatalasic carriers have been detected.

expected, since it has been demonstrated that cholinesterase, either pseudocholinesterase or a mixture of true and pseudocholinesterase, is not only present in avian ${ }^{5}$, but also in fish plasma. A positive cholinesterase activity was observed in Bowman's capsule, particularly for true cholinesterase, which finding may no doubt be related to the possible presence of these enzymes in fish plasma. The tubule walls were free, but the ureter wall stained heavily for both enzymes. In the contents of the lumen of tubules or ureter, no cholinesterases were demonstrated, however, which suggested that these enzymes are not being excreted except in quantities very much lower than present in the plasma or in a changed form. Between kidneys obtained from male and female fishes, no difference could be observed.

VAN DER KLOOT ${ }^{6}$ suggested that the cholinesterase is involved in the sodium pump mechanism, and consequently the presence of these enzymes in Bowman's capsule is possibly related to the renal function. GILBERT ${ }^{3}$ correctly observed that this suggestion must remain speculative until more is known about the physiological significance of these enzymes. As the cholinesterase

1 R. E. Coupland and R. L. Holmes, Quart. J. micro. Sci. 98, 327 (1957).

2 K. B. Augustinsson and D. Nachmansohn, Science 110, 98 (1949).

3 A. B. Gilbert, Nature 189,1009 (1961).

4 M. A. Gerebetzoff, Cholinesterases (Pergamon Press, London 1959).

5 K. B. Aucustinsson, Acta phys, scand. 15, Suppl. 52 (1948).

6 W. G. VAN DER KLOot, J. gen. Physiol, 41,879 (1958). 